\section{Morphological variations of languages in selected towns of the Fifth District of Leyte}

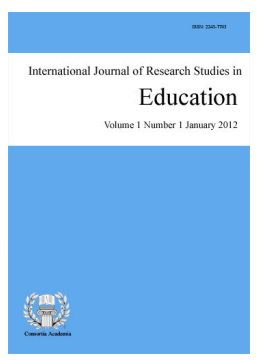

ISSN: 2243-7703

Accepted: 23 August 2021
Revised: 21 August 2021 DOI: $10.5861 / \mathrm{ijrse} .2021 . \mathrm{a} 058$

\title{
Abstract
}

This study aimed to find out the morphological variations of the dialects of the selected town of the fifth district of Leyte, Western Leyte. This study utilized a descriptive design wherein the researcher used two kinds of instruments. This study involved 125 respondents who were purposely selected according to age and location. Results revealed that the language of the selected town on the fifth district of Leyte, Western Leyte were composed of the root word, affixes, and repetition. There were 3 morphophonemic changes occurred: phonemic change, the omission of phonemes, and metathesis. It was found out that the following phonemes were freely exchanging vice versa without changing the words meaning such as; /l-w/, /m-n/, /i-a/ /a-u/, /l-k/, /s-l/, /r-n/, /r/, /d/, /r-h/, /g-s/, /u-i/, /h-k/, /s-t/, /j-y/, /w-t/ and /s-l/. Also, the study showed that in morphophonemic change there were phonemes that can exchange its position called metathesis. There was a morphological variation of the dialect of the selected towns of the fifth district of Leyte, Western Leyte. It was suggested that there will be a phonological study so that Western Leyte people can recognize suprasegmental phoneme variation.

Keywords: phonetic change, metathesis, mother tongue, omission of phonemes 


\section{Morphological variations of languages in selected towns of the Fifth District of Leyte}

\section{Introduction}

Language is considered as the window to the culture of the society where each citizen is rooted. This means that language will identify the source of the human race. It just proves that language reflects each individual whose manner of speaking and using the language depends on the society or location the speaker belongs to. It is essential to study our native language, especially now that there are many new sprouts of language that our youths are interested in. As a language teacher, I worried about the existing new languages because the researchers are afraid that the first language acquired of a baby might eventually die. It's not wrong to embrace the dynamic words since it only indicates that language is alive just don't let it forget you fully our first language. Heugh (2006), patronizing our native language is a good suggestion since students should be well-oriented in their first language before in another language.

RA 10533 presents the implementation of Mother Tongue-Based Multilingual Education (MTB-MLE) as a subject in teaching from Grade 1 to Grade 3. A problem exists for teachers due to a lack of resources. This is the reason why this study is developed that researchers do hope that will serve as a response to the problem of teachers teaching Mother Tongue. Relation to the implementation of the MTB-MLE, Cangco (2012) explained that the use of regional languages or mother tongue in teaching students helps to understand the lesson easily and most importantly, preserved the native language. Researchers have observed that many of today's teens are obsessed with dynamic words. This is why many of today's youth are gradually burying the native language to oblivion.

Pasion (2014) shared that through the study of language variations is an instrument to recognize the nature of their language. This is also supported by Akbuluta (2017) who stated that it is important for every individual to have knowledge of morphological variation in their own language. Mayfield, Nicholas, and McNamee (2009), also explained that each language has its own identity and therefore needs to be recognized to appreciate its variations. Morphological is the branch of linguistics that studies the morpheme or the smallest unit of a word that has meaning. Part of this is the system of using morphemes to produce words that are simple or complex in meaning. Researchers hope that the results of this study will be significant, especially for teachers who teach the mother tongue. This study aims to identify the morphological variations of languages in selected towns on the fifth district of Leyte.

\section{Methodology}

This study employed a descriptive method to obtain information on the current linguistic status of five municipalities in Leyte's fifth district. The researchers purposefully chose persons 50 years and older who were living in their hometown and could read and write from a total of 125 participants. The instrument utilized contains words that people often use in everyday communication, their daily lives, and their jobs. The researcher designed two instruments. The researcher began by creating a wordlist incorporating the language used by the participants. Second, the individuals were interviewed informally by the researchers. The prepared questions concern life, family, and social disasters. The participants' wordlists and words used in answering the questions were evaluated. Prior to completing the final analysis of the data, the researchers held a Focus Group Discussion with the participants to confirm the words had been translated into their own terminology. The data was collected during the participants' free time.

\section{Results and Discussions}

Word Formation - In the results of a survey of five towns of the fifth district of Leyte it was found that there 
Morphological variations of languages in selected towns of the Fifth District of Leyte

were three forms of words. The form is simple, repitition and the affixes. Table 1 clearly shows the terms dawu (selfish), init (hot), paspas (fast), suku (mad), tiil (foot), uwan (rain), and many others included in the simplified or basic form. Words that have an affix are the following hadlukan (fearful), from the root-word hadluk (fear), hingasuku (resentful) from the root-word suku, magtutudlo (teacher) from the root-word tudlo (teach), manggihatagun (generous) from the root-word hatag (give), and many more. Words that are in affix are words like kabatan-unan (youth), ipasigarbo (be proud), magbaktas (walk), katakus (ability), lunitun (tear-v.), naghinlit (stretched), gisugu (commanded), sinultihan (speech), and others. The example for repetition are the following; adlaw-adlaw (everyday), hinay-hinay (slowly), and others.

\section{Table 1}

Morphological variation of dialects of the Fifth District of Leyte by word format

\begin{tabular}{|c|c|c|c|c|c|}
\hline \multirow{2}{*}{$\begin{array}{c}\text { Words } \\
\text { Formation }\end{array}$} & \multicolumn{5}{|c|}{ Selected Towns of Leyte } \\
\hline & Bato & Hilongos & Hindang & Inopacan & Matalom \\
\hline \multirow[t]{18}{*}{$\begin{array}{c}\text { Simple/ } \\
\text { Basic Words }\end{array}$} & $\begin{array}{l}\text { Dawu } \\
\text { (selfish) }\end{array}$ & $\begin{array}{l}\text { Dawu } \\
\text { (selfish) }\end{array}$ & $\begin{array}{l}\text { Dawu } \\
\text { (selfish) }\end{array}$ & $\begin{array}{l}\text { Dawu } \\
\text { (selfish) }\end{array}$ & $\begin{array}{l}\text { Dawu } \\
\text { (selfish) }\end{array}$ \\
\hline & Init & Init & Init & Init & Init \\
\hline & (hot) & (hot) & (hot) & (hot) & (hot) \\
\hline & Kutu & Kutu & Kutu & Kutu & Kutu \\
\hline & (fast) & (fast) & (fast) & (fast) & (fast) \\
\hline & Paspas & Paspas & Paspas & Paspas & Paspas \\
\hline & (fast) & (fast) & (fast) & (fast) & (fast) \\
\hline & Pupuy & Pupuy & Pupuy & Pupuy & Pupuy \\
\hline & (feeble) & (feeble) & (feeble) & (feeble) & (feeble) \\
\hline & Suku & Suku & Suku & Suku & Suku \\
\hline & $(\mathrm{mad})$ & $(\mathrm{mad})$ & $(\mathrm{mad})$ & $(\mathrm{mad})$ & $(\mathrm{mad})$ \\
\hline & Tiil & Tiil & Tiil & Tiil & Tiil \\
\hline & (foot) & $($ foot $)$ & $($ foot $)$ & $(f o o t)$ & $(f o o t)$ \\
\hline & $\begin{array}{l}\text { Ulit } \\
\text { (greed) }\end{array}$ & $\begin{array}{l}\text { Ulit } \\
\text { (greed) }\end{array}$ & $\begin{array}{l}\text { Ulit } \\
\text { (greed) }\end{array}$ & $\begin{array}{l}\text { Ulit } \\
\text { (greed) }\end{array}$ & $\begin{array}{l}\text { Ulit } \\
\text { (greed) }\end{array}$ \\
\hline & Uwan & Uwan & Uwan & Uwan & Uwan \\
\hline & (rain) & (rain) & (rain) & (rain) & (rain) \\
\hline & Yuyu & Yuyu & Yuyu & Yuyu & Yuyu \\
\hline & (uncle) & (uncle) & (uncle) & (uncle) & (uncle) \\
\hline \multirow[t]{15}{*}{ Affix } & $\begin{array}{l}\text { Hadlukan } \\
\text { (fearful) }\end{array}$ & $\begin{array}{l}\text { Hadlukan } \\
\text { (fearful) }\end{array}$ & $\begin{array}{l}\text { Hadlukan } \\
\text { (fearful) }\end{array}$ & $\begin{array}{l}\text { Hadlukan } \\
\text { (fearful) }\end{array}$ & $\begin{array}{l}\text { Hadlukan } \\
\text { (fearful) }\end{array}$ \\
\hline & Hingasuku & Hingasuku & Hingasuku & Hingasuku & Hingasuku \\
\hline & (resentful) & (resentful) & (resentful) & (resentful) & (resentful) \\
\hline & $\begin{array}{l}\text { jawitan/banhaan } \\
\text { (noisy) }\end{array}$ & $\begin{array}{l}\text { jawitan/banhaan } \\
\text { (noisy) }\end{array}$ & $\begin{array}{l}\text { jawitan/banhaan } \\
\text { (noisy) }\end{array}$ & $\begin{array}{l}\text { jawitan/banhaan } \\
\text { (noisy) }\end{array}$ & $\begin{array}{l}\text { jawitan/banhaan } \\
\text { (noisy) }\end{array}$ \\
\hline & mabalak-un & mabalak-un & mabalak-un & mabalak-un & mabalak-un \\
\hline & (mindful) & (mindful) & (mindful) & (mindful) & (mindful) \\
\hline & $\begin{array}{l}\text { Magtutudlu } \\
\text { (teacher) }\end{array}$ & $\begin{array}{l}\text { Magtutudlu } \\
\text { (teacher) }\end{array}$ & $\begin{array}{l}\text { Magtutudlu } \\
\text { (teacher) }\end{array}$ & $\begin{array}{l}\text { Magtutudlu } \\
\text { (teacher) }\end{array}$ & $\begin{array}{l}\text { Magtutudlu } \\
\text { (teacher) }\end{array}$ \\
\hline & $\begin{array}{l}\text { Manggihatagun } \\
\text { (generous) }\end{array}$ & $\begin{array}{l}\text { Manggihatagun } \\
\text { (generous) }\end{array}$ & $\begin{array}{l}\text { Manggihatagun } \\
\text { (generous) }\end{array}$ & $\begin{array}{l}\text { Manggihatagun } \\
\text { (generous) }\end{array}$ & $\begin{array}{l}\text { Manggihatagun } \\
\text { (generous) }\end{array}$ \\
\hline & mang-uuma & mang-uuma & mang-uuma & mang-uuma & mang-uuma \\
\hline & (farmer) & (farmer) & (farmer) & (farmer) & (farmer) \\
\hline & mug-utun & mug-utun & mug-utun & mug-utun & Muruhun \\
\hline & (grouchy) & (grouchy) & (grouchy) & (grouchy) & (grouchy) \\
\hline & Simbahan & Simbahan & Simbahan & Simbahan & Simbahan \\
\hline & $\begin{array}{l}\text { (church) } \\
\text { Tapulan }\end{array}$ & $\begin{array}{l}\text { (church) } \\
\text { Tapulan }\end{array}$ & $\begin{array}{l}\text { (church) } \\
\text { Tapulan }\end{array}$ & $\begin{array}{l}\text { Tapulan } \\
\text { Thurchi }\end{array}$ & $\begin{array}{l}\text { Tapuwan } \\
\text { Tarch) }\end{array}$ \\
\hline & (lazy) & (lazy) & (lazy) & (lazy) & (lazy) \\
\hline \multirow[t]{4}{*}{ Repitition } & adlaw-adlaw & adlaw-adlaw & adlaw-adlaw & adlaw-adlaw & adlaw-adlaw \\
\hline & (everyday) & (everyday) & (everyday) & (everyday) & (everyday) \\
\hline & hinay-hinay & hinay-hinay & hinay-hinay & hinay-hinay & hinay-hinay \\
\hline & (slowly) & (slowly) & (slowly) & (slowly) & (slowly) \\
\hline
\end{tabular}

The results found in Table 1 indicates that it is very important for a person to be fully aware of the nature of his or her own language especially given that there are many dynamic words that young people are obsessed today. Öz (2014) shares that having teachers 'knowledge of the morphological variations of the language helps in 
Borong, N. L.

understanding in the language of his or her students if on what form of language there are speaking. Gallego (2018) also points out that learning a variety of languages is a great activity especially to linguistics. Researchers believe the teacher is a linguist. It is the responsibility of each teacher to convey and share knowledge to each student. The implementation of the MTB-MLE is a major challenge currently under the K to 12 Curriculum due to the lack of knowledge of the teachers teaching this subject and the lack of references. Saricoban (2014) states that with sufficient knowledge of morphology there is also the ability to comprehend the structural formation of a word. Researchers have personally noticed that many young people today use these dynamic words as the reason why they became foreign to their own language.

Table 2

Morphological variations in dialects of the Fifth District of Leyte according to morphological changes

\begin{tabular}{|c|c|c|c|c|c|}
\hline $\begin{array}{c}\text { Morphological } \\
\text { Changes }\end{array}$ & Bato & Hilongos & Hindang & Inopacan & Matalom \\
\hline \multirow[t]{38}{*}{ Phonemic Change } & bunal & bunal & bunal & bunal & bunaw \\
\hline & (spank) & (spank) & (spank) & (spank) & (spank) \\
\hline & bungul & bungul & bungul & bungul & bunguw \\
\hline & (deaf) & (deaf) & (deaf) & (deaf) & (deaf) \\
\hline & dira & diha & diha & dira & diha \\
\hline & (there) & (there) & (there) & (there) & (there) \\
\hline & habul & habul & habul & habul & habuw \\
\hline & (blanket) & (blanket) & (blanket) & (blanket) & (blanket) \\
\hline & kadiyut & kariyut & kariyut & kariyut & kadiyut \\
\hline & (moment) & (moment) & (moment) & (moment) & (moment) \\
\hline & kamagku & kumagku & kumagku & kumagku & kamagku \\
\hline & (thumb) & (thumb) & (thumb) & (thumb) & (thumb) \\
\hline & kapuy & kapuy & kapuy & kapuy & lapuy \\
\hline & (tired) & (tired) & (tired) & (tired) & (tired) \\
\hline & kural & kural & kural & kural & kuraw \\
\hline & (fence) & (fence) & (fence) & (fence) & (fence) \\
\hline & lakat & lakaw & lakaw & lakaw & lakat \\
\hline & (walk) & (walk) & (walk) & (walk) & (walk) \\
\hline & lihay & likay & likay & likay & lihay \\
\hline & (avoid) & (avoid) & (avoid) & (avoid) & (avoid) \\
\hline & mabdus & nabdus & nabdus & nabdus & mabdus \\
\hline & (pregnant) & (pregnant) & (pregnant) & (pregnant) & (pregnant) \\
\hline & sanina & sinina & sinina & sinina & sanina \\
\hline & (clothes) & (clothes) & (clothes) & (clothes) & (clothes) \\
\hline & sid-uk & sud-uk & sud-uk & sud-uk & sid-uk \\
\hline & (hiccup) & (hiccup) & (hiccup) & (hiccup) & (hiccup) \\
\hline & susiha & suliha & suliha & suliha & susiha \\
\hline & (inspect) & (inspect) & (inspect) & (inspect) & (inspect) \\
\hline & tara & $\operatorname{tana}$ & $\tan a$ & $\operatorname{tana}$ & $\operatorname{tana}$ \\
\hline & (let's go) & (let's go) & (let's go) & (let's go) & (let's go) \\
\hline & tukul & sukul & sukul & sukul & tukul \\
\hline & (resist) & (resist) & (resist) & (resist) & (resist) \\
\hline & tupad & tapad & tapad & tapad & tupad \\
\hline & (beside) & (beside) & (beside) & (beside) & (beside) \\
\hline & tapulan & tapulan & tapulan & tapulan & tapuwan \\
\hline & (lazy) & (lazy) & (lazy) & (lazy) & (lazy) \\
\hline & umigas & amigas & umigas & hulmigas & hulmigas \\
\hline & (ant) & (ant) & (ant) & (ant) & (ant) \\
\hline \multirow[t]{12}{*}{ Omission } & lingkud & lingkud & lingkud & lingkud & ingkud \\
\hline & (sit) & (sit) & (sit) & (sit) & (sit) \\
\hline & putdun & putdun & putdun & putdun & utdun \\
\hline & (cut off) & (cut off) & (cut off) & (cut off) & (cut off) \\
\hline & wana & wa & wa & wana & wana \\
\hline & (nothing) & (nothing) & (nothing) & (nothing) & (nothing) \\
\hline & dili & di & di & di & dili \\
\hline & (no) & (no) & (no) & (no) & (no) \\
\hline & unja & unja & unja & gunja & unja \\
\hline & (later) & (later) & (later) & (later) & (later) \\
\hline & kadyut & kadiyut & kadiyut & kadyut & kadiyut \\
\hline & (moment) & (moment) & (moment) & (moment) & (moment) \\
\hline
\end{tabular}

112 Consortia Academia Publishing (A partner of Network of Professional Researchers and Educators) 
Morphological variations of languages in selected towns of the Fifth District of Leyte

\begin{tabular}{|c|c|c|c|c|c|}
\hline & $\begin{array}{l}\text { saja } \\
\text { (skirt) } \\
\text { salindanaw } \\
\text { (dragonfly) }\end{array}$ & $\begin{array}{l}\text { sayal } \\
\text { (skirt) } \\
\text { alindanaw } \\
\text { (dragonfly) }\end{array}$ & $\begin{array}{l}\text { sajal } \\
\text { (skirt) } \\
\text { alindanaw } \\
\text { (dragonfly) }\end{array}$ & $\begin{array}{l}\text { sayal } \\
\text { (skirt) } \\
\text { alindanaw } \\
\text { (dragonfly) }\end{array}$ & $\begin{array}{l}\text { saja } \\
\text { (skirt) } \\
\text { salindanaw } \\
\text { (dragonfly) }\end{array}$ \\
\hline Metathesis & $\begin{array}{l}\text { Buak } \\
\text { (fragment) } \\
\text { Hagu } \\
\text { (tiresome) }\end{array}$ & $\begin{array}{l}\text { Buak } \\
\text { (fragment) } \\
\text { Gahu } \\
\text { (tiresome) }\end{array}$ & $\begin{array}{l}\text { Buak } \\
\text { (fragment) } \\
\text { Gahu } \\
\text { (tiresome) }\end{array}$ & $\begin{array}{l}\text { Buak } \\
\text { (fragment) } \\
\text { Hagu } \\
\text { (tiresome) }\end{array}$ & $\begin{array}{l}\text { Buka } \\
\text { (fragment) } \\
\text { Hagu } \\
\text { (tiresome) }\end{array}$ \\
\hline
\end{tabular}

Morphophonemic Change - Morphophonemic change refers to any changes that occurs in a morpheme due to the influence of environment. The adjacent sound causes the sound to change. In this study, it was found that five (5) selected towns of Leyte experienced three morphophonemic changes. It is phonetic change, omission, and metathesis.

Phonetic Change - It is noteworthy that the phonemes / 1 / of the towns of Bato, Hilongos, Hindang and Inopacan are replaced by / w / the town of Matalom which does not vary in meaning. Such as the word karal-kuraw (fence), bungul-bunguw (deaf), kanal-kanaw (ditch), habul-habuw (blanket), bunal-bunaw (spank), and many others. The phoneme / w / indicates that residents of Matalom has a unique dialect or language. This means that the / / / and / w / phonemes of the fifth district of Leyte are freely interchangeable or allomorph.

There are many words that have the opportunity to change positions especially in the town of Bato such as the word diha (there) and dira (there) used by most of the town of Bato. Similarly, in the town of Inopacan, the / $\mathbf{j} /$ that is commonly used in Bato, Hilongos, Hindang and Matalom, phoneme / $\mathbf{y} /$ is used in the town of Inopacan such as the word ajaw-ayaw (no), sajaw-sayaw (dance), and much more. Based on the interview conducted to the participants coming from the town of Inopacan, they are using the phoneme /y/ even though there is an influence in the place of Baybay, their town is just proportional to the town of island of Camotes that uses also phoneme /y/ in their speaking like ayaw (don't), maayo (good), di (no), and others.

This confirms what Pasion (2014) explained, that language variation is due to geographical factor. Constantino (2002) also shared, language diversity is due to the different or sparse locations of speakers of a language. It is stated that language differences or variations are related to location or geographical location.

Omission of Phoneme - The town of Matalom has a lot of omission of phonemes compared to other towns. It is noted that there is no consistency in when omission of phonemes occurs. There are phonemes missing in initial such as gunja-unja (later), putdun-utdun (cut off), kadiyut-kadyut (moment) and lingkud-ingkud (sit), there are also words and phoneme omission in the middle part of a word like kadiyut/ kadyut (moment) and phoneme omission in the final part of a word like saya/saja (skirt) from the word sajal/sayal (skirt).

It only indicates that the language of Leyte is like other languages such as the Filipino language that has word omission. Even with the missing phoneme still, the meaning will not change. From the article read by Marlett (c2014), it is stated that it is not surprising of the existence of omission and changing of phonemes in a word. Prior to the introduction of the formal alphabet of the Filipino language there is already an omission and changing just like for example to the words of Spanish language; bersiyon-bersyon (version), koneksiyon-koneksyon (connection), lico-liko (turn), and vintana-bintana (window) and much more.

Metathesis - This is a morphophonemic change that is moving or transfer because it involves the transfer of two phonemes that appear within the word. From the data gathered, the language of Leyte metathesis. The phoneme / ak / and / ka / / ha / and / ga / like in buak-buka (fragment), hagu-gahu (tiresome) that the meaning doesn't change. It is clear that in this study, there is a morphophonemic change in the language of Leyte.

It is evident that a large group causes a variant in this language to be different from its original language. According to Macatabon and Calibayan (2016), the existence of lexical and morphological variations is due to the geographical dimension or distance of the place in which they live. Macatabon and Calibayan (2016) cited this as a result of their examination of the B'laan language in the province of North and South Cotabato. The 
existence of lexical and morphological variations of the language is only proof that the language is not homogeneous.

Solis (2015) also shared, that the presence of language variation is a result of sociological and psychological factors. Social because a person will socialize and is interacting with his or her fellow and psychologically because a person wants to learn another language to say he is belonging to a group. They prefer to adapt to the majority so that they will not be underestimated.

In the researcher's findings it is noticed that there are many words that synonymous in meaning of the town of Bato and Matalom such as the word kadiyut (later) which in other towns it is called as kariyut (later), lakat (walk), and in the towns of Hilongos, Hindang and Inopacan they call it lakaw (walk), likay (avoid), it is called likay in the town of Hilongos, Hindang and Inopocan, and more. Based on the conducted Focus Group Discussion many from the Matalom said that some of the citizens are influenced by the town of Bato because there are many from the Matalom are everyday interacting the people of Bato since the town of Matalom and Bato are just close by. The town of Bato is the center of trade and commerce the reason there are many from the Matalom went to the town of Bato for trade and to buy their essentials in life. The researchers believe that this is one of the reasons why there is a similarity of some words that both towns used.

This result has a connection to the statement of Huisman JLA, Majid A, van Hout R (2019) that says, the dialect of a person depends on the location and geography where he or she belongs. But Rovira (2008), exclaimed that the language's influence on surrounding communities is a reason for concern because it is one of the factors that causes people to forget their own or native tongue. Researchers agree with the statement by Rovira (2008), because based on the questions from his / her students who belong in the city included in the study, many words were given to the participants that the students did not know.

This simply implies that the Leyte language has a unique characteristic that gives the Leyteños a distinctive identity. It shows that differences in language use indicate that individuals and groups are diverse, whether in their home, their interests, their activities, their education, and so on.

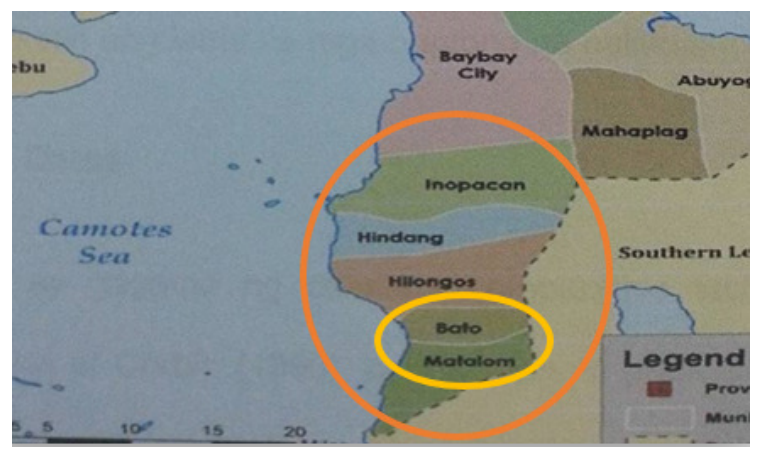

\section{Conclusion}

Geographical factors contribute to morphological variance in dialects in selected municipalities of Leyte's fifth district. There are words and expressions that are used by one group but not by others, and as a result, some sounds are not pronounced the same way or various words are used to indicate the same thing. The Leyteno language has been recognized as a distinct language as a result of this research. Further research on phonological variance in Western Leyte should be conducted in order to produce a booklet that can be used as a resource for teachers teaching Mother Tongue.

\section{References}

Akbuluta, F. D. (2017). Effects of morphological awareness on second language vocabulary knowledge. Journal of Language and Linguistic, 6(6), 565-572. https://doi.org/10.1111/j.1365-2524.2008.

Cangco, E., \& Santos, T. (2012). Wikang kinagisnan at 'K to 12. http://varsitarian. net/filipino/ 20120819/wikang_kinagisnan_at_k_to_12

Constantino, P. (2002). Varayti at varyasyon ng wika: historya, teorya at praktika. Unibersidad ng Pilipinas. Lungsod ng Quezon City.

Gallego, K. (2018). Directional systems in Philippine languages. Oceanic Linguistics, 57(1), 63-100. 
https://doi.org/10.1353/ol.2018.0002

Heugh, K. (2006). Theory and practice language education models in Africa. Research design in APEA optimizing learning and education (p. 235).

Huisman, J., Majid, A., \& van Hout, R. (2019). The geographical configuration of a language area influences linguistic diversity. PLoS ONE, 14(6). https://doi.org/10.1371/journal.pone.0217363

Macatabon, R., \& Calibayan, M. (2016). Varayti at varyasyon ng wikang B'laan sa Bacong, Tulunan, Hilagang Cotabato at Lampitak, Tampakan, Timog Cotabato, Philippines. Asia Pacific Journal of Multidisciplinary Research, 4(3).

Marlett, S. (2014). Phonology from the ground up: The basics. Retrieved from https://arts-sciences.und.edu/academics/summer-institute-of-linguistics/teaching-linguistics/_files/docs/ marlett-2014-phonology-student.pdf

Mayfield, J., Nicholas, C., \& McNamee, P. (2009). Addressing morphological variation in alphabetic languages. Proceedings of the 32nd international ACM SIGIR conference on Research and development in information (pp. 75-82). http://doi.org/10.1145/1571941.1571957

Öz, H., (2014). Morphology and implications for English language teaching. Linguistics for English language teaching studies. Procedia - Social and Behavioral Sciences, 136, 98-103. https://doi.org/10.1016/j.sbspro.2014.05.296

Pasion, R. (2014). Morpolohikal na varyasyon sawikang Mandaya ng Davao Oriental. Asia Pacific Journal of Education, Arts and Sciences, 1(5), 129-135.

Rovira, L. (2008). The relationship between language and identity. The use of the home language as a human right of the immigrant. REMHU-Revista Interdisciplinar da Mobilidade Humana, 16(31), 63-81.

Saricoban, A. (2014). Students' opinions of foreign language education on constructivist learning environment. Procedia - Social and Behavioral Sciences, 116, 2770-2773. https://doi.org/10.1016/j.sbspro.2014.01.653 
Borong, N. L.

116 Consortia Academia Publishing (A partner of Network of Professional Researchers and Educators) 